\title{
Mill and Cairnes and the Emergence of Marginalism in England
}

\author{
N. B. de Marchi
}

I

I $_{T}$ IS well known that marginalist concepts appeared in economic literature before 1871. As far as England is concerned, the notion of diminishing marginal utility, for example, was spelt out in the 1830 's and again in the 1850's. And Jevons hit upon and outlined his special view of political economy a full decade before the Theory of Political Economy was published.

For the most part, successive expositions of the utility theory were ignored by economists practicing in the dominant Ricardian tradition. This is not quite true of the leading adherents of that tradition, John Stuart Mill and J. E. Cairnes, who openly opposed it in certain respects. We have come to accept their opposition as entirely natural. But it is not self-evident that they should have opposed it. Indeed, Schumpeter has argued that Mill was influenced by Say and by Senior more than he was aware, or was prepared to admit, so that his system offered "all the elements of the complete model that Marshall was to build." "' Certainly Mill was early and (probably) independently in possession of isolated elements of marginalist theory-for instance, the notion of calculating, economic man and the principle of marginal cost pricing-which we tend rather to associate with Senior and W. F. Lloyd. ${ }^{2}$ Further, Mill was, in terms of his schooling, at least as well

NeIL B. DE MARCHI is Assistant Professor of Economics at Duke University. 1. J. A. Schumpeter, History of Economic Analysis (New York, 1954), pp. $529-30,569-70$.

2. Compare [Mill] "The Nature, Origin, and Progress of Rent" (1828) in Collected Works of John Stuart Mill (Toronto, continuing), 4:163-80, esp. pp. 166-67, and "On the Definition of Political Economy; and on the Method of Investigation Proper to It" (1836), ibid., pp. 309-39, at p. 323, and also "War Expenditure" (1824), ibid., pp. 3-22, at pp. 16-18, with B. J. Gordon, "W. F. Lloyd: A Negleeted Contribution," Oxford Economic Papers, n.s. 18 (1966) : 6470, at pp. 69-70, and Schumpeter, pp. 575-76. 
fitted as Jevons to develop an "hedonic calculus." 3 Then, too, Mill and Cairnes were well versed in the writings of the so-called French school, with whom, according to Jevons, the truth (about distribution) really lay. ${ }^{4}$ Cairnes was even an intimate of Leonard Courtney, who broadly adhered to this "school" and was one of the two men in England-after Fleeming Jenkin and George Darwin-who Jevons thought might appreciate Walras's work..$^{5}$

Why, then, did Mill and Cairnes fail to develop their theoretical structure in the same direction as Jevons? To provide an answer to that question is the task of this essay. ${ }^{6}$

\section{II}

It is convenient to begin by listing the principal theoretical advances embodied in Jevons' political economy.

There is, firstly, the distinction between total and "final" utility, and the enunciation of the law that to a buyer the utility of a commodity diminishes as successive increments of it are acquired and consumed. ${ }^{7}$

Secondly, there is the explicit assumption of maximizing behavior, and the statement of what it implies-for consumers, that purchasing

3. Cf. R. D. C. Black, Introduction to the Pelican Classics (1970) ed. of W. S. Jevons, The Theory of Political Economy (1871), p. 30.

4. The expression "French school" was used both by Jevons and by Mill and Cairnes. Jevons meant by it the tradition of regarding commodities and factor services as subject to the same laws of value-in-exchange, and it is employed above in that sense. For a list of writers included by Jevons in this tradition, see Preface to the $2 d$ ed. of his Theory of Political Economy (1879), p. xlix.

5. See Black, Introduction, pp. 32-33. Leonard Courtney was professor of political economy at University College, London, 1872-75. He published little on economic theory, but his adherence to the "French school" is sufficiently shown by two anonymous pieces: "Economistes Modernes," London Review 5 (12 July 1862) : 35-37 and 5 (2 Aug. 1862): 106-8; and "Mr. Thornton on Labour," Times, 16 Oct. 1869 , p. 4.

6. The enquiry is not as open-ended as this way of putting the question implies. We start with the knowledge that Mill and Cairnes shared roughly the same set of economic notions as Say, Senior, Longfield, Jennings, and Jevons. (In particular, they were familiar with the concept of the margin and the general notion of satiety.) What is at issue for the most part, then, is not why Mill and Cairnes failed to discover notions which these, and other of their contemporaries, hit upon, but what kept them from extending, applying, or combining common notions in precisely the same way as their contemporaries 9 To be specific, why, possessing the notion of the margin, did they not arrive at a clear distinction between total and marginal utility 8 And why, being familiar with satiety, did they not enunciate the principle of diminishing (marginal) utility

7. Jevons, Theory, 2d ed., pp. 49-57. 
should be so spread that the ratios of utilities derived from the last units consumed of each desired commodity are equal to the ratios of their prices. ${ }^{8}$

Thirdly, there is the insight that value in exchange is the pivot of the economic process, the laws of value applying equally to commodities and to agents of production, since factors or agents are rewarded out of the value of the product for which they are jointly responsible. In the case of both agents and commodities there is "a general balance of producing power and of demand as measured by the final degree of utility.",

Of course, Jevons' Theory of Political Economy contained other novelties-notably his discussion of capital and interest—but the three outlined are the ones most relevant to our purpose.

In what sense and in what measure were our two representatives of Ricardian thought aware of these ideas? And, insofar as they were known and understood, what stood in the way of their being developed within the Ricardian tradition?

\section{III}

We take up these questions firstly in relation to the distinction between total and marginal utility, and the law of diminishing marginal utility.

Marshall was inclined to see in Ricardo's differentiation of "value" from "riches" a hint that he had been "feeling his way towards the distinction between marginal and total utility." Marshall continued:

For by Riches he means total utility, and he seems to be always on the point of stating that value corresponds to the increment of riches which results from that part of the commodity which it is only just worth the while of purchasers to buy; and that when the supply runs short . . there is a rise in that marginal increment of riches which is measured by value, at the same time that there is a diminution in the aggregate riches, the total utility, derived from the commodity.

All that Ricardo lacked, Marshall suggested, was the language in

8. Ibid., pp. 63-66, 198-201, 205-9.

9. Ibid., Preface, pp. xlix-lii, and pp. 204, 295-96. 
which to express this neatly_ "the terse language of the differential calculus." "10

Marshall's assessment was overgenerous. If this was indeed the direction of Ricardo's thought, and the calculus the one tool lacking, it would be reasonable to expect his able follower John Stuart Mill to have arrived at a clear statement of the distinction. For Mill knew that price usually varies inversely as the quantity offered for sale. Also, he made more explicit than Ricardo the idea that the price prevailing in a market at a given time indicates that buyers consider it just worthwhile to purchase the last unit offered at that price. ${ }^{11}$ Further, he had the advantage over Ricardo of having read Senior's -admittedly brief-exposition of the principle of diminishing marginal utility. ${ }^{12}$ Finally, while he was, on his own admission, less thoroughly grounded in the calculus than in algebra and geometry, nevertheless, his mathematical education was sufficient to enable him to perceive possible applications of the distinction between a differential increment and a sum. ${ }^{13}$ Yet Mill, in discussing the gain from

10. Marshall, Principles of Economics, 9th (variorum) ed., ed. C. W. Guillebaud, 2 vols. (London, 1961), 1:814.

11. On these points see Mill's essay, "Of the Laws of Interchange Between Nations; and the Distribution of the Gains of Commerce Among the Countries of the Commercial World," in Collected Works, 4:232-61, at pp. 237-38; his review article, "De Quincey's Logic of Political Economy"' (1845), ibid., pp. 393-404, at pp. 399-401; and his Principles of Political Economy, with Some of Their Applications to Social Philosophy (1848), Collected Works, 3:465-68.

12. Mill's notes on Senior's An Outline of the Science of Political Economy (1836) are to be found reprinted in Economica, n.s. 12 (1945): 134-39.

13. For Mill's admission see J. Stillinger, ed., The Early Draft of John Stuart Mill's Autobiography (Urbana, Ill., 1961), p. 42. It was made concerning his education from age 8 to age 12 . For the list of his mathematical reading during that period, which included some works on fluxions, see Francis E. Mineka, ed., The Earlier Letters of John Stuart Mill, 1812-1848, vols. 12 and 13 of Collected Works, at 12:7-8. Mill's mathematical training was, however, extended during a visit to France in 1820, when he worked partly under the supervision of M. P. Lenthéric, professor of higher mathematics in the Faculté des Sciences, Montpellier. By the end of this visit Mill had worked through Lacroix's Traite $d u$ calcul différentiel et du calcul intégral (1814), Lagrange's Théorie des fonctions analytiques (1813) and Laplace's Exposition du système du monde (1813)performing "over and over" all the problems in Lacroix's work. For further details see Anna Jean Mill, ed., John Mill's Boyhood Visit to France (Toronto, 1960), pp. 29, 82, 86, 88, 90. (The dates of the French works listed above are those of the editions in Mill's library at Somerville College, Oxford.) Mill's library contains these and other works by the same authors, and William Whewell's Doctrine of Limits (1838). We know too that Mill was familiar with De Morgan's Differential and Integral Calculus (1842): see Mill's essay, "Berkeley's Life and Writings,' Fortnightly Review n.s. 10 (Nov. 1871): 505-24, at pp. 521-22. Over- 
trade, wrote as if the total gain were measured by the terms of tradean apparent conflation of marginal with total utility for which he was sharply criticized by Jevons. ${ }^{14}$ More basically, Mill showed no inclination to set down laws of consumer behavior, let alone laws of enjoyment resolvable into quantities of pleasure and pain.

One important factor in Mill's hesitancy is readily explained. He knew that different individuals experience a particular pleasure with different intensity. This difference might be attributed to a difference in circumstances; but even if the circumstances are common, he said, they may produce different effects because the characters of the persons involved differ. Indeed, the causes determining human character are "so numerous and diversified ... that in the aggregate they are never in any two cases exactly similar." Hence, even in given circumstances, "no assertion, which is both precise and universally true, can be made respecting the manner in which human beings will think, feel, or act."15

Mill's methodological caution, it should be stressed, was reserved for attempts to specify precise and universal laws of behavior: laws which might be regarded as rules or precepts, applicable without thought for the possible peculiarities of each case. ${ }^{16}$ However, this

all, Mill's mathematical education probably was not inferior to that available to Cambridge undergraduates in the early 1820 's; on this see W. W. Rouse Ball, $A$ History of the Study of Mathematics at Cambridge (Cambridge, 1889), chap. 7. Clearly, however, an adeqaute training in one discipline is not a guarantee that its techniques will be seen as applicable to the problems of another. Conversely, this perception may be present when the technical skill to exploit it is lacking. Malthus in 1829 confessed to "never having been very familiar with the present algebraic notation," yet saw that "there are many of the results in political economy which have some resemblance to the problems de maximis et minimis." Malthus to William Whewell, 26 May 1829, Whewell Papers, Trinity College, Cambridge.

14. Mill, Principles, Collected Works, 3:615; Jevons, Theory, 2d ed., pp. 154-56.

15. Mill, A System of Logic, Ratiocinative and Inductive, 2 vols. (London, 1843), 2:494, 506-7. In the latter passage Mill suggested that differences of "mental susceptibility" may be "original and ultimate facts," or "consequences of ... previous mental history," or related to differences in the constitution or physiology of different indiviauals.

16. Cf. Mill's opposition to certain political economists (among whom he classed Robert Lowe) for their apparent readiness to identify political economy with " a set of catch-words, which they mistake for principles-free-trade, freedom of contract, competition, demand and supply, the wages fund, individual interest, desire of vealth, \&c.- which supersede analysis, and are applicable to every variety of cases without the trouble of thought." "Professor Leslie on the Land Question"' (1870), in Collected Wortes, 4:671-95, at p. 671. 
still left it plenty of scope. For just as Mill was sensitive to the fact that the desire of different individuals for the same commodity might vary in strength, so too he recognized that there is no uniform relation between price and the quantities demanded of different commodities. Thus,

some things are usually affected in a greater ratio than that of ... [a given] excess or deficiency, others usually in a less : because, in ordinary cases of demand, the desire, being for the thing itself, may be stronger or weaker: and the amount of what people are willing to expend on it, being in any case a limited quantity, may be affected in very unequal degrees by difficulty or facility of attainment. ${ }^{17}$

Money alone, of all commodities, he said, is desired as "the universal means of purchase"; and its value tends to vary in inverse proportion as its amount. Again, though Mill asserted, in his discussion of international exchange, that the terms of trade adjust to the "inclinations and circumstances of the consumers on both sides," he left the precise result unspecified. For, "as the inclinations and circumstances of consumers cannot be reduced to any rule, so neither can the proportions in which the ... [traded] commodities will be interchanged." 18

In the light of this it is not surprising that Mill in 1871 reacted negatively to Jevons' attempt to express the laws of consumer behavior in mathematical form. It mattered little whether it was a demand schedule or a schedule of variations in utility that was translated into symbols. In either case, Mill might have said, an important principle governing the use of scientific language was being violated. For Mill regarded algebraic relations as universal technical rules, applicable, without regard to the meaning of the signs or the peculiar circumstances of each case, only where the investigation comprised ascertaining a relation between mere numbers. In his view the laws of consumer behavior were preeminently not of this sort; and in investigating such subjects, he said, "the things on which we reason should be conceived by us in the concrete, and 'clothed in cir-

17. Principles, Collected Works, 3:512; cf. p. 467.

18. "Of the Laws of Interchange Between Nations," in Collected Works, 4:239-40. The passage was repeated in the Principles, Collected Works, 3:598-99. 
cumstances." "10 Jevons, Mill suggested, had "a mania for encumbering questions ... . with a notation implying the existence of greater precision in the data than the questions admit of." 20

Mill's followers Cairnes and Cliffe Leslie held similar views, and they displayed much the same reaction to Jevons' Theory of Political Economy. ${ }^{21}$

The belief that mechanical reasoning should not be applied to consumer behavior no doubt blinded all three to the clarity which Jevons' mathematics imparted to the notion of the margin. Nonetheless, mathematics was not essential to the concept of marginal utility nor to the principle of diminishing (marginal) utility. Supplementary reasons must therefore be sought to explain why Mill and his followers failed to arrive at these ideas. Four will be suggested here.

Firstly, Mill inherited from Ricardo a bias against giving consumption a place equal to that held by production and distribution in the schema of economic science. "Political economists," Mill averred, "have never treated consumption on its own account, but always for the purpose of the enquiry in what manner different kinds of consumption affect the production and distribution of wealth." 22 In part this was a defensive pose, adopted lest any concession appear to be made to those who believed in the possibility of a general glut. ${ }^{23}$ And in part it reflected the Ricardian concentration on long-run, competitive value, as distinct from short-run or market

19. System of Logic, 2:292-98.

20. Mill to Cairnes, 5 Dec. 1871, Mill-Taylor Collection, vol. LV, British Library of Political and Economic Science.

21. In a letter of 23 Oct. 1871 to Mill, Cairnes wrote, apropos of Jevons' book: "I own I have no faith in the development of economic doctrines by mathematics. What you have said on the subject of nomenclature in the second vol. of your Logic seems to me decisive upon this point." Mill-Taylor Collection, vol. LVIA. See also Cairnes's review of the work: "New Theories in Political Economy," Fortnightly Review, n.s. 11 (Jan. 1872): 71-76, at p. 76 . Leslie's views are given in his review of the $2 \mathrm{~d}$ ed. of Jevons' Theory. The Academy, 26 July 1879 , pp. $59-60$.

22." On the Definition of Political Economy," in Collected Works, 4:318 n.; cf. his views on the place of the theory of value, Principles, Collected Works, $3: 455$.

23. Although the main battles on this point had been fought before 1830 , Mill maintained his opposition to the "chimerical supposition" (as he referred to it) in the Principles. See Collected Works, 2:66-68 and 3:570-76. Cairnes, as late as 1874, evidently felt it necessary to reiterate the grounds of that opposition. See Cairnes, Some Leading Principles of Political Economy, Newly Expounded (London, 1874), pp. 17-34. 
value. Given sufficient time, the Ricardians believed, the value of a commodity whose supply can be increased will conform to the cost or supply price of the particular amount of it demanded. Conversely, they urged, a great demand, unattended by "some principle of limitation in the supply," is not sufficient to induce a high price. ${ }^{24}$

For Mill, then, there was to be no approach to marginal utility theory via the investigation in its own right of consumption and the laws of enjoyment. This position was reinforced by a technical objection to the idea that demand might be measured subjectively, according to the intensity of desire (or anticipated satisfaction). This notion had appeared in Senior's Outline of the Science of Political Economy. If a shortage of wheat occurs, Senior had said, the consumers of oats and barley will not thereby have any greater power of purchasing these substitute commodities, nor will the quantity of them which is purchased increase, supply being given. There is, however, a sense in which the demand for them may be said to increase, namely, that they are now desired in greater degree than before. ${ }^{25}$ Mill, commenting on this suggestion, rejoined that there would be more purchasers at the previous market price, and in this sense an increase in demand. Furthermore, this sense was to be preferred; since if one is to speak of a law of demand and supply, these two things must be expressed in comparable terms:

Now as ordinary usage makes it almost impossible to use the word supply in any sense but that of quantity of the commodity, viz., the quantity actually in the market or ready to be brought into it, demand must I think be used also in the sense of quantity of the commodity, and in that sense it can only be taken to mean, the quantity for which at the market price, purchasers can be found. ${ }^{26}$

Mill repeated this argument in his Principles of Political Economy (1848). ${ }^{27}$

It is possible, thirdly, that Mill's methodological convictions exerted

24. Mill, Principles, Collected Works, 3:475-76; “Nature, Origin, and Progress of Rent,"' Collected Works, 4:164.

25. Senior, Outline of the Science of Political Economy (reprint ed., 1938), p. 15.

26. "Notes on N. W. Senior's Political Economy, by John Stuart Mill," Economica, n.s. 12 (1945): 134.

27. Collected Works, $3: 465$. 
a critical influence. Recall for a moment his view that no precise and universal laws of human feeling or action are to be found. At the same time Mill did allow that this standpoint was unnecessarily strict for many practical purposes. Frequently it is found, he said, that a few general causes, and qualities common to large bodies of men (though not to all mankind), will yield propositions which are "almost always true." Mill called these approximate generalizations, or observation statements, "empirical laws." However, they could not be regarded as truly scientific laws until they were resolved into the basic causes of the phenomena they described..$^{28}$ Now the law of diminishing marginal utility was of this purely empirical variety. ${ }^{2 \theta}$ On Mill's view, then, to use this law to explain the shape of the demand curve would amount to setting one unexplained uniformity to explain another. ${ }^{30}$ Outside the context of maximizing behavior, such a substitution must have appeared peculiarly sterile.

If the "empirical" law of diminishing marginal utility was itself to be explained, the explanation would have had to run in terms of the laws of psychology. The psychology adopted by Mill was the socalled associationist psychology. One of its laws stated that "greater intensity in either or both of ... [two] impressions, is equivalent, in rendering them excitable by one another, to a greater frequency of conjunction." 31 This was not meant to imply that a more intense pleasurable sensation is reducible to a greater number of confrontations of the senses with a desired object. Such a supposition would be contrary to the commonsense implications of satiety. What was in view was the efficiency of the stimulus-response mechanism. It was not unreasonable to suppose that excitation would be more effective if a

28. System of Logic, 2:494-96.

29. Senior and Richard Jennings represented the law as a matter of common experience. Senior, pp. 11-12; Jennings, Natural Elements of Political Economy (London, 1855), pp. 98-99. Jevons actually called it an empirical law. Theory, $2 d$ ed., p. 159.

30. Jevons himself regarded the law of diminishing marginal utility as an exploratory device. He doubted whether "any exact explanation" of the laws of utility could be given, and likened them to "the empirical formulae used in many of the physical sciences-mere aggregates of mathematical symbols intended to replace a tabular statement." Theory, $2 \mathrm{~d}$ ed., p. 159.

31. Mill, System of Logic, 2:501. Cf. James Mill, Analysis of the Phenomena of the Human Mind (1829), a now edition, with notes illustrative and critical by Alexander Bain, Andrew Findlater, and George Grote, edited with additional notes by John Stuart Mill, 2 vols. (London, 1869), 1:82-90. 
particular stimulus-response association was more frequently renewed. Nonetheless, the strict adherent of this psychology might be excused for failing to arrive at a clear conception of marginal satisfaction. Not only was attention directed more to the conjunction of sensations than to the senations themselves, but, although "degrees of pleasurable sensation" were sometimes spoken about, there was no clear separation made between the sensation itself and the degree of pleasure which might go together with it. As late as 1869 John Mill could write, in a cautious note to his father's Analysis of the Phenomena of the Human Mind, that

it is open to question whether the pleasure or pain, especially the pleasure, is not something added to the sensation, and capable of being detached from it.... It is often observable that a sensation is much less pleasurable at one time than at another, though to our consciousness it appears exactly the same sensation in all except the pleasure. This is emphatically the fact in cases of satiety, or of loss of taste for a sensation by loss of novelty. ${ }^{32}$

Mill concluded that it is in principle possible to abstract the pleasure or pain attending a sensation from the sensation itself and to consider the pleasure or pain alone. However, he made no attempt to exploit this possibility or to show what implications it might hold for the study of human enjoyment.

Associationism did not constitute an absolute barrier to the clear conception of marginal satisfaction. Richard Jennings proceeded on the basis of the associationist psychology, yet he enunciated with remarkable clarity the principle that the "degrees of satisfaction" derived from consuming a commodity diminish with each installment of it offered to the senses. ${ }^{33}$ It is significant, however, that Jennings had long been dissatisfied with the Ricardian theory of value and was deliberately casting about for an hypothesis which could equally well explain-as the cost of production theory could not-such diverse phenomena as why light, air, and water generally command no price;

32. In James Mill, 2:185.

33. Jennings, pp. 96-99. A useful statement of Jennings' views is given by Ross M. Robertson, "Jevons and his Precursors," Econometrica 19 (1951) : 22949, at pp. 234-37. 
why silks vary less in price with a given change in quantity than do potatoes; and why a copy of the Times which costs fourpence in the morning falls to tuppence when the evening news is out. ${ }^{34}$ Mill, by contrast, felt no such inducement to investigate the laws of enjoyment.

Lack of interest in the laws of enjoyment led to blunted perception. Thus Cairnes, who was the only one of Mill's disciples to comment on Jennings' work, dismissed it with the comment that no new light had been thrown on production, division of labor, and exchange by Jennings' attempt to exhibit the psychological and physiological bases of these phenomena of wealth. ${ }^{35}$

To summarize: Mill had specific reasons for not wanting to admit into economic science the study of human wants and the laws of enjoyment. These reasons had to do with his belief that the forces of supply were of prime importance. Consistently with this, he insisted that in speaking of demand and supply a measure of demand must be adopted conformable with that-namely, quantity-in terms of which supply is commonly understood. He therefore deemed unsatisfactory a subjective measure of demand. Further, it is probable that Mill would not have accepted the law of diminishing marginal utility as a genuine explanation of the shape of the demand curve. But in any case, his adherence to associationist psychology made it unlikely that he would enunciate even this "empirical law" for himself.

An assessment of the relative importance of these several reasons will be held over till after the examination of the position of Mill and Cairnes with respect to the other new elements in Jevons' Theory of Political Economy.

\section{IV}

The central figure in Jevons' calculus of pleasure and pain was the utility-maximizing individual. Mill based his own political economy on the not dissimilar assumption that man is "determined, by the

34. Jennings, pp. 84, 97, 210-11; idem, Social Delusions Concerning Wealth and Want (London, 1856), pp. 70-71.

35. Cairnes, The Character and Logical Method of Political Economy (1857), $2 d$ ed. (London, 1875), Appendix B. Cairnes also protested against Jennings' suggestion that "such relations as those of Quantity and Value... may be exhibited in the formulae and analyzed by the different methods of Algebra and of Fluxions.' Jennings, pp. 259-60 ; Cairnes, Character and Logical Method, 2d ed., pp. 110-12 n. 
necessity of his nature, to prefer a greater portion of wealth to a smaller," save only that he is averse to labor and also prefers the present enjoyment of the fruits of his efforts. Mill added that man is "capable of judging of the comparative efficacy of means" to the attainment of wealth. In other words, he assumed man to be motivated by "the desire of obtaining the greatest quantity of wealth with the least labour and self-denial." ${ }_{36}$ We have seen that Mill's acquaintance with the idea of satiety did not impel him in the direction of the law of diminishing marginal utility. Nor did his readiness to deduce economic laws from the premise that man desires wealth and is calculating in its pursuit lead him to enunciate the theorem that if a maximum of satisfaction is to be derived from any good (including labor or money) capable of satisfying different wants, it must be allocated to these different uses in such a way as to equalize its marginal utilities in all of them. ${ }^{37}$ Nonetheless, Mill's thinking approached most closely to Jevons's at this point.

The closeness of their views is obscured by Mill's concern with minimizing real cost or sacrifice, rather than with maximizing utility. But, as the following examples show, he had firmly grasped the essence of the optimizing procedure-the ordering of alternative possible uses of resources in terms of their respective effects on some maximand (say, output) or minimand (such as cost). Thus, Mill opposed the Corn Laws because, he said, under their influence "a portion of the labour and capital of the country is diverted out of a more into a less advantageous employment: a quantity of labour is employed in growing corn, which would otherwise have produced, not only cloth, or hardware, sufficient to purchase the same quantity of corn in the foreign market, but much more." 38 Similarly, Mill judged the Saint-Simonian system of cooperation superior to that proposed by Robert Owen, because he thought it likely to be more efficient. According to the former scheme each man was to be employed "according to his capacity," and his reward "proportioned as far as possible to his services." Owen, however, advocated that individuals "be freely permitted to receive from the general store of the community whatever 323.

36. "On the Definition of Political Economy," in Collected Works, 4:321-22,

37. Cf. Schumpeter, pp. 910-11.

38. [Mill] "The Corn Laws" (1825), in Collected Works, 4:47-70, at pp. 51-52. Cf. the discussion of discriminating duties in Principles, Collected Worles, 3:847-48. 
they may require," irrespective of the value of their particular contribution. This policy, Mill believed, would weaken the incentives to work; as a result, the "powers of production" would not be called into full activity. ${ }^{39}$ Both these examples deal with society's allocation of its resources. Right social policy was indeed Mill's chief concern. ${ }^{40}$ But the process of individual maximizing behavior did not wholly escape his attention. In an exchange of letters with Cairnes, Mill outlined a case where a consumer is unable to afford as much as he would like of each of two commodities, and he is therefore forced to "share his demand" between them. His "apportionment of selfdenial," Mill suggested, is likely to vary with the relative prices of the commodities, and in such a way-so Mill's phrasing implies-as to reduce the total of forgone satisfaction to a minimum. ${ }^{41}$

This last example directs us to the elements separating Mill from Jevons. What was lacking in Mill's treatment was a statement as to just how far consumption should proceed in each direction for the optimum result to obtain. ${ }^{42} \mathrm{He}$ was prevented from spelling this out by his not having the notion of marginal utility (in this instance, disutility), or the principle-essential to a maximum or minimum solution-that marginal utility diminishes as successive units of each

39. Owen, Report to the County of New Lanark (1820), in G. D. H. Cole, ed., Robert Owen: A New View of Society and Other Writings, Everyman Library (London, 1963), pp. 245-98, at p. 289; also Mill's "Closing Speech on the Cooperative System" a speech delivered at the Cooperative Society Debates of 1825, reprinted as "Further Reply to the Debate on Population," Archiv für Sozialwissenschaft und Sozialpolitik 62 (1929): 225-39, at p. 232; and his anonymous article, "St. Simonism in London," Examiner, 2 Feb. 1834, p. 68.

40. In one sense, Mill's concentration on social policy may be said to have made it unnecessary for him to develop a detailed theory of individual maximizing behavior. Choices, if acted upon, will issue in observable behavior. Assuming, then, that social conflicts, if they appear, are resolvable according to some set of higher criteria, nothing more need be postulated about private maximization than that each individual, being informed about alternatives, knows what he wants and pursues it. On the other hand, even if a theory of individual utility. maximization is developed, it may be deemed inapplicable to the social sphere because of the difficulty of making comparisons of satisfactions between persons. This, we know, was a problem of which Mill was very much aware: see, for example, Hugh S. R. Elliot, ed., The Letters of John Stuart Mill, 2 vols. (London, 1910), 2:116.

41. Mill to Cairnes, 5 Jan. 1865, printed in Appendix H of Mill's Principles, Collected Works, 3:1089. The other portions of the exchange are also contained in this Appendix.

42. In the other two examples given, complete adoption of one of the alternative courses of action meant that the analogue of this problem on the side of production did not arise. 
commodity are consumed (marginal dissatisfaction increases as less of each commodity is available for consumption).

Some possible reasons why Mill did not possess these notions have been examined in the preceding section. The same reasons suffice to account for his inability to transform the postulate of man as a calculating seeker after wealth into the precise rules of behavior which Jevons derived from the maximization principle. It needs only to be added that, from the present viewpoint, Mill's prohibition against the use of mathematics may have been as critical to the final result as was his unwillingness to enquire directly into the laws of enjoyment. The obvious tool for elaborating the assumption of maximizing behavior was the differential calculus. Had Mill applied it, he might have been led to the distinction between total and marginal utility in the process of interpreting his mathematical results.

\section{$\mathrm{V}$}

We turn next to Jevons' insight that the laws of value apply equally to commodity prices and to the rewards of the agents of production. In a long preface to the second edition of his Theory of Political Economy he wrote : "we must regard labour, land, knowledge and capital as conjoint conditions of the whole produce," and the share of each in that produce as "entirely subject to the principles of value and the laws of supply and demand." 43 This was said by way of showing in which general direction "a true doctrine of wages" must be sought. Jevons did not claim to have worked out the details of the theory of distribution hinted at in these passages, but he saw clearly that it would run counter to several characteristic features of the Ricardian theory of distribution. For example, the ideas that agents jointly determine final output and that each must bargain for "the best share of the produce which the conditions of the market allow him to claim successfully" upset the doctrine that rent forms no part of value and is determined quite independently of "normal" wages and profits.

In outlining his own approach to distribution Jevons indicated that he thought he was only restating a view which had been held by a series of French writers, from Condillac, through Say, to Bastiat and Courcelle-Seneuil. Mill and Cairnes knew the works of most of these

43. Jevons, Theory, 2d ed., Preface, pp. 1-li. 
writers, but they esteemed them much less highly than did Jevons. From their criticisms-especially those of Cairnes-we may hope to learn something of why they preferred their own views on the relation between value and distribution.

These criticisms were wholly methodological. Mill placed great stress on the importance in science of attending carefully to nomenclature and classification: that is, to the names of kinds of things and the arrangement of those kinds into larger classes. He commented on the latter process: "The ends of scientific classification are best answered, when the objects are formed into groups respecting which a greater number of general propositions can be made, and those propositions more important, than could be made respecting any other groups into which the same things could be distributed." Cairnes accepted Mill's views and from this standpoint offered an assessment of Courcelle-Seneuil and Bastiat.

Of Courcelle-Seneuil's Traité théorique et pratique d'économie politique (1858) Cairnes wrote:

The chief fault I find with it is-what I think is characteristic of the French school-a tendency to vicious generalization ... which, instead of elucidating, darkens the problems. Thus he regards abstinence as a form of labour, rent as a form of interest. Capital is made to cover land as well as wealth in general. . . It is of course only by dint of straining language that he can make his facts fit into this framework; and thus a sort of haze is thrown over the whole exposition. ... ${ }^{45}$

A similar comment might have been made about Bastiat's writings. ${ }^{46}$ Indeed, in an essay published late in 1870, and which had Mill's approval, Cairnes argued that Bastiat's central results were founded upon "the shifting uses of an ambiguous term."

44. Mill, System of Logic, 2:302.

45. Cairnes to Mill, 13 Jan. 1870, Mill-Taylor Collection, vol. LVIA. Mill had previously written to Cairnes saying that, in his view, French political economists shared largely in the defects of French philosophic writers in general, these being "decidedly inferior in closeness and precision of thought to the best English." Mill to Cairnes, 16 Nov. 1869, Mill-Taylor Collection, vol. LV.

46. Compare the points singled out in the passage quoted with pp. 178, 179, 182, 277 of Bastiat's Economic Harmonies, trans. W. Hayden Boyers, ed. George B. de Huszar (Princeton, 1964).

47. "Bastiat," in Cairnes, Essays in Political Economy, Theoretical and Applied (London, 1873), pp. 312-44, at p. 337. 
The term was "service." "Value," Bastiat had written, "is the relation of two services exchanged." He applied this doctrine to all useful objects and acts, including property in land, as well as labor and capital. The ambiguity of which Caimes complained lay in the fact that "service" might stand, and was intended by Bastiat to stand, for such disparate elements in value as the degree of usefulness, scarcity, and effort embodied in a commodity or act, plus the subjective judgment of the consumer and the pains which he is spared by the fact that others supply the commodity or act which he desires. ${ }^{48}$ Cairnes insisted that no single term could embrace these varièd and distinct conditions and still retain explanatory power. He compared Bastiat's theory unfavorably with Ricardo's on these grounds. Thus,

Ricardo, seeking to ascertain the laws to which exchange-value in its various manifestations conforms, analyzes the various conditions under which the phenomenon is found to present itself, classifies them according to their essential distinctions, marking these distinctions by distinct names [monopoly values, (competitive) "market" and "natural" values, domestic and international values], and is thus enabled to show in what way and under what circumstances each class contributes to the ultimate result-the phenomenon of value.

Cairnes continued:

To tell me ... that value represents "service" and varies with "service" is to tell me nothing, unless I am told further the elements of "service" which are operative in the given case. This is what Ricardo's theory in effect does: this is what Bastiat's theory fails to do. ${ }^{49}$

48. Bastiat, Economic Harmonies, pp. 105-6, 143-45.

49. "Bastiat," in Cairnes, Essays, pp. 338, 340. In an anonymous review of Cairnes's Essays in Political Economy Jevons dissented from the author's estimate of Bastiat. "On the whole, we think that Mr. Cairnes might have discovered more merit in Bastiat. ... He remarks that the most recent and important works on political economy, those, for instance, of M. Courcelle-Seneuil, make little reference to Bastiat, so that he has no following; but we are much mistaken if the general disposition of the subject by Seneuil, followed since by Professor Hearn, of Melbourne, in his "Plutology," is not derived from Bastiat. While Mr. Mill has most erroneously denied that consumption of wealth is a branch of political economy, Bastiat logically commenced with human wants and 
Elsewhere, Cairnes made precisely the same criticism of Jevons' use of the term "utility." of Thornton's On Labour, sought to comprehend the cost-of-production theory of value under an extended form of the law of demand and supply, Cairnes evidently felt that an important distinction was thereby obscured, and he wrote to state his emphatic dissent. ${ }^{51}$

Not surprisingly, then, when Cairnes faced the specific suggestion that the phenomena of wages, profits, and rent might be elucidated by the same theory as explains the value of commodities, he expressed a serious doubt whether a comprehensive formula could be found to do the job. Certainly, he agreed, relative rewards can be ascertained by applying the laws of value. But the problems of commodity prices, on the one hand, and of the positive returns to agents, on the other, were in his view "essentially discrepant." Cairnes objected in particular to the idea that the two problems can be reduced to one by considering each as amenable to the law of demand and supply. Confining himself to the question of wages, he urged that commercial motives, whereby the supply of commodities is adjusted to the demand, do not apply to the supply of labor. To adapt a single formula to these distinct cases would, he said, issue in solutions either true merely by verbal shifts, or false to the real facts. ${ }^{52}$ Similarly, Cairnes implied that an attempt to treat land and its reward on the same basis as "the ordinary products of industry" would violate the fundamental truth that products directly or indirectly using land as an input-but only they-are subject to the limiting principle of diminishing returns. ${ }^{53}$

made the consequent demand and consumption of commodities the natural basis of the science of human wealth. It is probable that when the true logical order of treatment of the doctrines of the science comes to be carefully reconsidered, the order adopted by Mr. Mill will be rejected, and that of Bastiat more nearly followed." Manchester Guardian, 10 April 1873, p. 6.

50. Cairnes, Some Leading Principles, pp. 11-16.

51. Cairnes to Courtney, 1 Sep. 1869, Courtney Collection, vol. I, British Library of Political and Economic Science. Courtney had written: "the normal or natural as much as the temporary or market value of any commodity depends upon an equilibrium of supply and demand; for, though it is strictly measured by the cost of production under the most unfavorable circumstances under which production is sustained, that range of circumstances is attained only when the quantities produced and brought to market (supply) is equal to the quantities withdrawn from market and consumed (demand)." Times, 16 Oct. 1869, p. 4.

52. Cairnes, Some Leading Principles, pp. 173-79.

53. "Bastiat," in Cairnes, Essays, pp. 327-28, 343. For Mill's views on the 
In both these instances Cairnes drew attention to disparities in the conditions governing the supply of commodities and agents as his reason for ruling the law of demand and supply inapplicable to the problem of the average rate of wages and to the determination of rent. Certainly he was right to attend carefully to the forces of supply. But he failed in not asking seriously whether a basis for applying the laws of value to factor rewards might be found on the side of demand. To account for this failure it will be helpful to recall Mill's criteria for a good classification. They were two: that it bring out the most numerous, and the most "important," features peculiar to the kinds of things under scrutiny. Mill admitted that what is "important" may vary with the object in view; "and the same objects, therefore, may admit with propriety of several different classifications." ${ }_{54}$ Now Cairnes was interested primarily in the average remumeration enjoyed by the whole class of workers or capitalists, and the causes influencing the average well-being of all classes taken together, in questions such as, Why is the return to capital and labor higher in one country than in another? and, Why is it progressing faster in one than another ${ }^{255} \mathrm{His}$ interest in these questions, plus his Ricardianism, made him jealous for a classification which brought out, for example, the distinctiveness of the motives governing the supply of labor, and of the forces governing the rate of return in agriculture and related industries. Had Cairnes given more attention to the question of the relative rewards of different laborers and capitalists amongst themselves, and had he been less set against supply-and-demand analysis, he might have come to see, as Marshall did, that the demand for factor services is a derived demand, that for short periods at least price governs cost, and that the rewards of specific types of labor and capital may embody an element of quasi-rent. As it was, he quite failed to appreciate that with the aid of the new principle that values are governed by marginal utility, the value of the product due to an agent of production, and its value to a consumer, may "with propriety" be classified anew, and begin to be investigated, as aspects of a single problem.

significance of the principle of diminishing returns see Principles, Collected Works, $2: 173$.

54. Mill, System of Logic, $2: 305$.

55. Cairnes, Some Leading Principles, p. 174. 
On this interpretation, then, it was Cairnes's choice of problems, together with the ordering of causal factors from which solutions to his chosen questions flowed, that separated him from Jevons and the French tradition of treating value and distribution by the same general laws.

\section{VI}

A number of partial explanations have now been offered as to why Mill and Cairnes failed to take the steps necessary to reach the Jevonian position. These steps were of three kinds:

1. The fashioning of new tools: for example, marginal utility, and the law of diminishing marginal utility;

2. A redirection of interests and a rewriting of procedural rules, so that the new tools seemed relevant and appropriate (examples of this are the switch in emphasis from the supply side to wants and demand, and the decision to employ mathematics);

3. The envisaging of a unified economic science, organized around the notion of utility maximization.

The relative significance of the reasons outlined above varies according to which step is being considered. ${ }^{56}$

We have not been much occupied with discovery, since the concept of marginal utility and the law of diminishing (marginal) utility were accessible, and actually known, to Mill (in the work of Senior) and to Cairnes (in the writings of Jennings and-almost certainly-of Longfield). The only factor among those mentioned which bears on discovery is the associationist psychology; this made it unlikely that Mill would forge the link between satiety and the idea of diminishing marginal utility.

What of the factors inhibiting Mill and Cairnes from appropriating this idea? Here two things are pertinent. On the one hand there are Mill's methodological convictions, from which we can infer that he would have said that nothing more is explained by speaking of diminishing satisfaction than by saying that a lowering of price

56. The separation of the steps is not complete, nor the ordering fixed. Thus the concept of marginal utility was formed before the new vision, yet without the latter this concept would not have been seen to be of such wide applicability. 
is usually necessary if potential buyers are to be induced to consume more of a particular commodity. And, on the other hand, there is the fact that both Mill and Cairnes were interested mainly in questions which could be answered without paying any special attention to the laws of enjoyment. There is no way of knowing which of these factors weighed more heavily in their thinking. Mill's rejection of a subjective measure of demand, however, follows naturally from, and therefore probably was secondary to, his interest in the supply side of things.

So far as the vision of a unified economic science is concerned, here too methodological factors and the orientation of their interests both played a part in circumscribing the view taken by Mill and Cairnes, though in this case methodological factors were secondary. No doubt their methodological belief that mathematical reasoning ought not to be applied to wants and enjoyment prevented them from grasping the significance of Jevons' mechanics of utility maximization. But what really stopped them from treating value and distribution as aspects of a single problem was their insistence that land is different and that labor is not simply a commodity. And this insistence, in turn, stemmed from a concern with typically Ricardian problems-the price of food, and the average standard of comfort of the laboring class (in the determination of which laborers were supposed to be capable of exercising choice)-and a commitment to Ricardian solutions to those problems.

Overall, it is probable that Mill and Cairnes were more constrained by their initial selection of questions to be tackled and by their special view of what constituted adequate answers than by their methodological beliefs. For Jevons was acutely conscious of the methodological pitfalls in what he was doing, and he expressed much the same doubts about them as Mill and Cairnes. ${ }^{57}$ Yet he was not deterred from exploring, as potentially illuminating, lines of thought which simply failed to spark any interest in them. ${ }^{58}$

57. See, Jevons, Theory, chap. 1.

58. This essay was prepared while the author was supported by a Nuffield Foundation Dominion Travelling Fellowship. Thanks are due to the Foundation and to Professor A. W. Coats for his helpful comments on an earlier version. 